\title{
A TERÜLETI EGYENSÚLYOK VÁLTOZÁSA 1997 ÉS 2002 KÖZÖTT
}

\author{
(Changing States of the Regional Equilibria \\ between 1997 and 2002)
}

\author{
BARTKE ISTVÁN
}

Kulcsszavak:

horizontalis egyensúly vertikális egyensúly korreláció-és regresszió analizis

A területi arányok (különbségek) és egyensúlyok vizsgálatához általában az ún. horizontális terïleti modellt alkalmazzák, anelynek révén az egymás mellett elhelyezkedö területi egységek azonos tartalnut elemeik (pl. a munkaerö stb.) közönti különbségek szämszerïsíthetök. Emellet fontos szerepet kaphat az ün. vertikális modell is, anzely terileti egységeken (régiókon sth.) beliil a különbözö tartalmú elemek egymás közötui mennyiségi kapcsolatát tárja fel (pl. munkahely - munkaerö-lakás stb.). A horizontális modell számításai egyszerü esetben - hagyományos eszközökkel is megoldhatök, a vertikális modellhez igénybe kell venni a korreláció- és regresszió-analízis eszköztárát. Ez thóbbival viszont számszerüsíthetök a tényezöpáronkénti vertikális egyensúlyi állapotok, valamint meghotározhatók a hozzajuk tartozó megyei értékek.

Fokozottan kisérleti jelleggel regionális szinten is végeziink számitást, és lehetséges volt néhány tényezöre korrelációs mátrix kidolgozása is. A megyei szintü vizsgálat keretében 35 tényezópár korrelációs együtthatóját számítottuk két vetületben (Budapesttel, illewe anélklll). A számítási eredmények elemzésekor csak a legfontosubbnok tartout kapcsolatok szóbeli bemutatásár, tértink ki. Úgy gondoltuk ugyanis, hogy a korrelációs egyiitthatók, azok idỏbeni és térbeni változásai eléggé "beszédesek”, továbbá a tanulmány egy andonányos hipotézist kiván igazolni. Nem a terjedelem bővítésétöl függ, hogy ez sikerïl-e?

A társadalom és a gazdaság területi elhelyezkedése, térbeli arányainak folyamatos átalakulása, ezen belül a települések létrejötte, állandó - nagyságrendet, szerkezetet stb-t érintő - változása, mint spontán irányzat összefoglalóan a területi (regionális) fejlódés fogalmával jelölhető meg. A nagy összefüggésrendszerböl esetenként ki szokták emelni a településfejlódést, mint önálló folyamatrendszert; ez azonban csak annyiban indokolt, amennyiben a településfejlödésnek, mint a területi fejlödés sajátos megnyilvánulásának, az általánostól eltéró vonásait kívánják vizsgálni. E megállapítás annak aláhúzása miatt célszerü, hogy leszögezhessük, a területi fejlődés általános törvényszerúségei a telepủlésre, mint térségi rendszerre is érvényesek.

Induljunk ki abból a tételezésbỏl, hogy a regionális fejlődés - kvázi piacgazdasági feltételek mellett - spontán folyamat. Ez azt jelenti, hogy a térbeni arányok, struktúrák egyedi szereplők, állampolgárok, vállalkozók össztevékenységi vállalatok letelepítése, lakások, szolgáltatások stb. térbeni elhelyezése eredményeként alakulnak ki. Vajon igaz-e az előző feltételezés? Csak részben; a társadalmi tevékenységek meghatározott részére és bizonyos térbeli korlátok mellett igaz. Éppen a kiemelt településfejlődés egyik sajátossága, hogy a piacgazdasági hatások csak szürőkön keresztül érvényesülhetnek. 
A település, mint társadalmi-gazdasági képződmény kiegyensúlyozott müködésének fontos feltétele, hogy a viszonylag kis területen koncentráltan települt nagy tömegü gazdasági létesítmény (szervezet) és ember mindegyikének érdekei érvényesíthetök legyenek. Ehhez szabályozott kereteket kell létrehozni, amelyek lehetövé teszik a gazdaság szereplőinek egymás közti zavartalan kapcsolatát, az emberek mobilitását, a munka- és szolgáltató helyek elérését, a kultúrált környezet megteremtését stb., általánosságban szólva a települési infrastruktúra kiépítését. Mindez tervek és szabályok megalkotásával érhetỏ el, amelyek kijelölik a társadalmi és gazdasági szereplők számára az igénybe vehető területeket, a közlekedési pályák vonalvezetését, a hálózati elemek elhelyezését, a rekreációs és zöldterületeket stb. Települési szinten tehát elengedhetetlen rendezési tervek és hozzájuk tartozó szabályok kidolgozása (függetlenül azok megjelenési formájától). A településrendezési tervek, szabályok korlátokat állítanak a spontán fejlödés elé, amely szükséges az élhetö belső környezet és a külső kapcsolatok szempontjából. A spontán fejlődésböl településszinten így, bizonyos mértékig, társadalmilag szabályozott fejlödés lesz. A piacgazdaság ezen a szinten abban tér el pl. a tervgazdaságtól, hogy a rendezési tervek által felállított keretek szabadabban tölthetők ki, nagyobb szerep jut az egyéni vállalkozói döntésnek; az elöző esetben viszont az elhelyezhetó beruházásokat is központilag jelölhetik ki.

A településrendezés elméletét, tartalmát, a spontán folyamatokba való beavatkozás határait stb.-t illetően is léteznek eltérő álláspontok, azonban aligha tagadható, hogy a legliberálisabb felfogás is elengedhetetlennek tekinti rendezési tervek és szabályok alkalmazását a gyakorlati életben, és így a spontán települési stb. folyamatok korlátozását. Ismét hangsúlyozzuk, hogy mindez a településben élő emberek, mủködö vállalkozások, intézmények stb. érdekében történik. A településrendezési tervek és szabályok minősége (hatásfoka) lényegében azon mérhető, hogy azok milyen kereteket adnak a rendkívül sokféle és gyakran egymásnak ellentmondó egyéni és közösségi érdekek érvényesítéséhez, az eltérő érdekek optimális összehangolásához, végsỏ soron az életminőség javításához. A szabályozás hatósági jellege ezen a szinten és szférában erősen kidomborodik.

Nem kívánjuk most abban az irányban folytatni a gondolatmenetet, hogy vajon a területnagyság növekedésével, illetve a gazdasági és népességi koncentráció csökkenésével hogyan változik a (spontán) területi fejlỏdés tartománya, miként alakul át az elöbbit korlátozó tényezők jellege. Valószínünek tetszik azonban, hogy a terület növekedésével (kistérség, megye, régió, ország stb.) növekszik az autonóm, kevésbé szabályozott térségi folyamatok köre, a szabályozásban nő a gazdasági eszközök szerepe a hatóságiakhoz képest. A népsürúség, a gazdasági szereplök területegységre jutó számának csökkenésével, a térnek, mint erőforrásnak a mérséklődő kihasználása ugyanis gyengíti, nem élezi ki az azt igénybe vevök közötti érdekkonfliktusokat. Ez az összefüggés természetesen akkor logikus, ha a területnagyság (illetve a vizsgált területi egységek) növekedésével párhuzamosan a tér igénybevétele (pl. a népsürüség) csökken. A kérdés mélyebb vizsgálata mindenesetre új kutatási eredményeket ígér. 
Eddigi gondolatmenetünkben (a településfejlődésröl mondottak révén) eljutottunk a területi (regionális) fejlödés határmezsgyéjéig. Ettől kezdve új fogalom lép életbe, a szüken értelmezett, a több település területére kiterjedő terület (regionális) fejlesztésé. Mibenlétét a településfejlődés spontán folyamatainak szükséges korlátozásáról elmondottak kapcsán már érintettük. Itt hangsúlyoznunk kell, hogy a település(rendezési) tervezés és szabályozás nemcsak korlátozást, hanem a terület-felhasználás - mindenkori értékrendet követő - kijelölését is szolgálja. Természetesen a településnél nagyobb térségeket illetỏ területfejlesztési politikában is előfordulhatnak korlátozások, ezek azonban nem rendszeres elemei az előbbinek. A területfejlesztés aktív befolyásoló szerepe mindenekelőtt a fejlesztési célok és eszközök meghatározásában, illetve az eszközök, továbbá az intézményi keretek kijelölésében fejezödik ki.

A telepuilésnél nagyobb térségekre kiterjedő területfejlesztés főként a 20. század közepe óta az országok növekvő körében vált az állami (regionális) irányítás elemévé. Mindenkori céljainak kitüzéséhez behatóan elemezni kell a területi folyamatokat, a spontán megnyilvánultakat éppúgy, mint a korábbi szabályozásból levezethetőket. Ennek eredményeire kell (kellene) építeni, a rendelkezésre álló anyagi eszközökkel kombináltan az országos területfejlesztési politikát. A területi elemzések mennyiségi és módszertani apparátusa az 1990. évi rendszerváltás óta ugrásszerü fejlődést mutat; a kutatások elmélyítése azonban további feladat (Rechnitzer 2005). Tanulmányunkban kísérletet teszünk arra, hogy újszerü közelítéssel elemezzük a területi egyensúlyoknak, mint a területi struktúra, fejlődés, politika fontos tényezőinek alakulását az 1997 és 2002 közötti fél évtized során hazánkban. A jelen munka csak a településnél nagyobb térségek egyensúlyi problémáit taglalja. Településszinten a szabályozott tartalmú rendezési és fejlesztési tervek az egyensúlyi fejlődést is elömozdítják, más oldalról pedig a nagyobb térségre jellemzö egyensúlyi összefüggések gyakran a helyi irányitás által közvetetten a településre is érvényesülnek.

\section{A területi egyensúly tartalma és irányai}

A területfejlesztési politikák által megfogalmazott egyik legfontosabb (ha nem a legfontosabb) cél kezdetektỏl az azonos nagyságrendü térségek közötti gazdasági fejlettségi különbségek kiegyenlítése (vagy inkább mérséklése). A „Williamson hipotézis" szerint a régióközi fejlödési folyamatban a jövedelmi különbségek kezdeti növekedését, a fejlödés második szakaszában azok csökkenése követi, ennek eredményeként a hátrányos helyzetủ térségek felzárkóznak a fejlettekhez. Ez az egyensúlyi modell szemben áll a komparativ költségek elméletével. Más nézetek szerint, ha a többrégiós gazdaságot külső hatás éri, akkor a gazdagabb régiók profitálnak többet. (Területi egyensúlytalansági modell) (Nijkamp 1990). A magyar gyakorlat mindkét modell érvényesülésére tartalmaz példát, azzal, hogy a területi egyensúlyi fejlödés főként a tervgazdaságban, állami beavatkozás révén valósult meg; 1990 (illetve még korábbi évek) óta, a kvázi piacgazdasági feltételek között a területi jövedelmi szintekben föként távolodás (differenciálódás) tapasztalható. Az. utóbbi tendencia azért nem meglepő, mert a magyar gazdaság a rendszerváltozásig 
koránt sem érte el azt a fejlettségi szintet, amely után automatikusan kibontakozhatott volna a fejlődés második szakaszára jellemzỏ nivellálódási folyamat.

A differenciálódás ellen az állami teruletfejlesztési politika - részben a gazdaság gyengesége miatt - nem rendelkezett megfelelö eszközökkel; azok csak a területi gazdasági különbségek még nagyobb elmélyülésének megakadályozására voltak elégségesek. Esetleg fordulatot hozhat az Európai Uniótól nyerhetö jövőbeni nagyobb támogatás; ennek kapcsán is meggondolandó azonban, hogy a támogatási eszközöket, még ha az formális eredményeket hozhatna is, szabad-e és milyen mértékig a törvényszerü folyamatok semlegesítésére felhasználni. Ez a kérdés, mint a területfejlesztési politika egyik dilemmája aligha ítélhető meg csupán a régiók közötti gazdasági közelítés (a horizontális egyensúly) oldaláról, mérlegelésbe kell vonni a vertikális egyensúly követelményeit is, amelyekröl később részletesen lesz szó.

Visszatérve azonban a régiók (területi egységek) közötti közelítés kérdésére, a rövidebb távlatú dilemmák nem mondanak ellent annak, hogy általánosságban a regionális tudomány legelsỏ kérdésfeltevése (paradigmája) a térbeni társadalmi egyenlőtlenségek köre és azok kezelési módja (Nemes Nagy 2003) legyen. A Williamson-hipotézis tartalma azonban jelentösen bövült; az eredeti formájában a területi jövedelmi különbségeket foglalta magában. A térbeni társadalmi egyenlötlenségek kezelése, mint a területfejlesztési politika talán legfontosabb feladata rendkívül bonyolult, tekintettel arra, hogy azok számos elemének területi eltérései természetüknél fogva - nem küszöbölhetők ki, illetve mérséklésük társadalmilag nem kívánatos. A területfejlesztési politika végsö céljának karakteres megfogalmazása miszerint: „,Az nevezhető korrekciót igénylö társadalmi-területi egyenlötlenségnek, ami egy adott társadalmi státusú egyén számára csupán lakóhelye miatt lényegesen rosszabb életfeltételeket vagy társadalmi mobilitású esélyeket nyújt, mint amilyennel egy hasonló társadalmi státusú egyén egy másik régióban rendelkezik." (Enyedi 1996, 121) Természetes, hogy a jelzett cél eléréséhez a területfejlesztési politikának számos feladatot kell vállalnia, amelyek jelentös részben ugyan nivellációs jellegủek; komplex megítélésükhöz azonban a vertikális egyensúlyi modellt is alkalmazni célszerü.

A társadalom és a gazdaság horizontális térbeni rendeződésén, a térelemek, mint település, vonzáskörzet, régió stb. (Nemes Nagy 1998, 87) egymásmellettiségén, vagyis a horizontális egyensúlyi szférán túl a vertikális irány és szféra is definiálható. Ez a társadalmi emberi lét feltételeinek, egyes sajátosságainak, megnyilvánulásainak egymásra épülését modellezi, mint természeti, mủvi és társadalmi környezet, gazdaság, életmód, értékrend, ideológia (Bartke 2001). A jelzett tényezők között kölcsönhatás-jellegü kapcsolatok vannak, azok mennyiségileg és minőségileg meghatározzák egymást. A modell és az általa involvált viszonyok különbözö térségi szinteken, földrajzi pontonként, térelemenként stb. vizsgálhatók. A központban az ember, illetve a társadalom áll, reá irányulnak a létfeltételek és belöle indulnak ki a korszerüsítési törekvések, mind az anyagi, mind pedig a szellemi szférára hatóan. Egyensúlyról - ebben a közelítésben - akkor beszélhetünk, ha a tényezök mennyiségi és minőségi összetétele az érintett emberek, társadalmi csoportok számára, a vizsgált térségi kereten belül kedvező életminőséget alapoz meg, valamint, az előzőtől nem 
függetlenül, hatékony gazdálkodást tesz lehetövé. Egy-egy lokalizáltan megjelenő és felhasználható tényező mennyiségileg és/vagy minőségileg nem megfelelő volta felborítja a mindenkori (időben és térben változó) vertikális egyensúlyt.

Ha az egyén (társadalmi csoport) szempontjából (1. fentebb Enyedi megfogalmazását) vezetjük le a területfejlesztés végső célját, akkor a kiinduló helyzet vizsgálatakor a horizontális és a vertikális modell a valóság különbözö oldalait tárja fel. Ezért együittes alkalmazásuk indokolt. Tekintsük át logikailag, hogy az érdekviszonyoknak milyen szerep jut a kétféle modellben. Könnyen belátható, hogy maguk ama különbségek, amelyek az egyes régiók, vagy más területi egységek (települések, kistérségek, megyék stb.) között fennállnak, a reálszférát, tehát a jövedelem szintjét, az ellátottságot stb., általában az életminőséget tekintve aligha befolyásolják az egy adott településben, kistérségben, régióban települt ember és családjának megélhetési viszonyait. Az a tény, hogy valamely más, alacsonyabb vagy magasabb fejlettségü régióban élő hasonló státusú ember, társadal mi csoport életminősége jobb vagy rosszabb az övéknél, nincs közvetlen hatással a saját viszonyokra. A vizsgálat alanyai tehát közvetlenül nem érdekeltek a régiók közötti különbségek mérséklésében.

Némileg más a helyzet - az anyagihoz képest - a szellemi szférát tekintve. Az életkörülmények területi különbségeinek tudatosulása ronthatja a hátrányos helyzetü területeken élö állampolgárok közérzetét, és elégedetlenségi mozgalmak kialakulásához vezethet. Mindenekelőtt a területileg immobilis társadalmi csoportokban, mivel az elmozdulásra képes és kész, a helyi viszonyaival elégedetlen népesség elvándorolhat, és elvileg ott telepedhet meg, ahol életigényei jobban kielégíthetök (v.ö.: Enyedi 1996, 121). A dolgok dinamikáját, jelen esetben a területi egységek között gazdasági közelítést tekintve változhat a kép, erősödhet az egyének, társadalmi csoportok (másodlagos) érintettsége a folyamat által, mégpedig aszerint differenciáltan, hogy az érdekeltek viszonylag fejlettebb vagy elmaradottabb régióban élnek-e. Nyilvánvaló a gazdaságilag kedvező helyzetben lévő területeken élők ellenérdekeltsége a regionális közelítéssel szemben; ezzel ellentétes a hátrányos helyzetü területek társadalmának viszonya a folyamathoz.

Ismét hangsúlyozzuk, hogy megállapításaink demokratikus, (kvázi) piacgazdasági mechanizmust múködtetö társadalomra vonatkoznak. Tehát a területi fejlödés az egyes emberek, társadalmi csoportok elhelyezkedésében, helyi tevékenységben gyökerezik. A társadalom és a gazdaság, azok különbféle elemeinek, tényezőinek területi arányai „spontán” módon, társadalmi beavatkozás nélkül alakulnak ki. A különbözö térségek közötti gazdasági stb. különbségék - első közelítésben - a helyi eröforrások mennyiségi, minőségi eltéréseire (böségére vagy szükösségére), továbbá azok felhasználásának hatékonyságára vezethetők vissza. Ez utóbbi másodlagos folyamatot táplál, nevezetesen a mobilis erőforrások koncentrálódását az azokkal hatékonyan gazdálkodó térségekre, amely tovább növelheti a gazdasági és más különbségeket. A gazdasági szereplő tehát a rendelkezésére álló erőforrások minél jobb hasznosításában érdekelt. Ezek, valamint az egyes emberek, társadalmi csoportok életviszonyait meghatározó tényezők a vertikális egyensúlyi modell segítségével tarthatók fel és elemezhetök. A fejlődés, illetve a területi irányítás korai fázisá- 
ban tehát, amíg nem bontakozik ki a területi nivellálódás automatizmusa, erős marad a társadalmi szolidaritás szerepe a hátrányos helyzetü térségeket illetően.

A vertikális egyensúly vizsgálata, szemben a horizontáliséval, nem térségközi, hanem térségeken belüli mủvelet. Ez utóbbinak nincs térbeni korlátja, elméletileg a különbözö (ilyen szempontból számításba vehető) földrajzi pontoktól kezdve, a szórványtelepüléseken, községeken, nagyvárosokon, régiókon, országokon keresztül országcsoportokig alkalmazható. A horizontális egyensúlyi modellnek, amenynyiben azt - alapértelmezés szerint - a jövedelmi viszonyok elemzésére használják, alsó térbeni határa a megye vagy a régió, illetve, a modell elemeit tekintve a kistérség. Ennek nemcsak statisztikai, hanem a területi folyamatok jellegében gyökerezö okai is vannak, nevezetesen kistérségen belül nincsenek olyan, tartalmilag homogén egységek, amelyekre a területi közelítés fogalma értelmezhetö lenne. Ugyanez a helyzet a társadalmi funkciókat térben megosztó települések esetében is.

A vertikális egyensúly elemzésekor egy adott lakóhelyen, telephelyen élỏ ember, társadalmi csoport, müködő vállalat tágan értelmezett környezeti viszonyaiból indulunk ki, feltárjuk, hogy melyek azok a feltételek amelyek az adott vállalat hatékony müködéséhez, az emberek kedvező életviszonyaihoz stb. szükségesek. A környezeti feltételek döntően helyi jellegüek, azaz a vállalatok illetve a lakóhelyek közvetlen közelségében helyezkednek el, kisebb részük szélesebb körben jelenik meg, (térbeni) hatásuk azonban a telephelyeken stb. koncentrálódik. A termelésben, szolgáltatásban, az életminöség alakításában - döntöen kistérségi szintig - szétszórtan elhelyezkedő tényezők, amennyiben azok telephelyi, települési pontokra összpontosulva hatnak, helyi tényezőknek minősülnek. A telephelyen, a lakóhelyen stb. érvényesülö impulzusok természetesen nagyobb térségü körökböl is származhatnak, ezek azonban számszerủen elenyészőek, jóllehet hatásuk igen erőteljes lehet, pl. valamely fejlesztési támogatás allokálása egy vállalatra vagy térségi pontra.

Konkrétabban: a vállalkozás telephelyén összpontosulva, egymást erösítve jelenik meg a természeti tényezöknek az infrastruktúra kiépítettségének, a foglalkoztatott emberek szakképzettségének, innovációs készségének és munkamoráljának stb. hatása a gazdasági, szolgáltató tevékenység eredményességére. Az emberek lakóhelyi környezetének minöségét döntően a levegö, a víz, a talaj tisztaságának foka, illetve szennyezettsége, a foglalkoztatási lehetőségek mennyisége és struktúrája (úgy is, mint a jövedelemszerzés forrásai), az épített környezet kapacitásai és minősége, a szolgáltatásokhoz való hozzájutás lehetösége stb. határozzák meg. Mindez újból aláhúzza a telephely szerepét a hagyományos (helyi és regionális) gazdaságban, és kiemeli a központi telephely jelentőségét a globális szférában (v.ö.: LengyelRechnitzer 2004, 57). A vertikális irányú, mikroszférára kiterjedő vizsgálat mezo- (és makro-) szintü megfelelője a gazdálkodás feltételeinek, az életminőség tényezőinek stb. feltárása települési, kistérségi, megyei, regionális stb. szinteken belül. A „helyi szint" kiterjedése tehát változik; a megnevezés itt azt jelenti, hogy az adott terület „belső”, vertikális összefüggéseit vizsgáljuk, más térségektől függetlenül. 


\section{Az alkalmazott módszerek}

Vizsgálatunk kiterjed a horizontális és a vertikális egyensúly alakulására is, a súlyt azonban az utóbbira helyezzük. A területközi (horizontális) elemzés természetesen azonos tartalmú társadalmi tényezőkre vonatkozhat, azt lehet vizsgálni, hogy a különböző területi egységekben mekkora a jövedelem szintje, az egyes szolgáltatási kapacitások abszolút és viszonylagos nagysága stb., és a területileg eltérö adatok elemzésével vonhatók le következtetések, az adott homogén elemekre vonatkozóan. Ez a módszer alkalmatlan a minőségileg eltéró tényezők területi kapcsolatának vizsgálatára. Így van ez akkor is, ha figyelembe vesszük, hogy rendkívül gazdag módszertani apparátus áll rendelkezésre a heterogén elemek egyes csoportjainak összevonására és az e mutatók által keltett új minőségek elemzésére. Az egyes terülteken megvalósult, egy-egy tényezőt illető változást kifejezhetjük a hagyományos dinamikus mutatóval. Amennyiben egy-egy tényező területi egységek szerinti dinamikáját, illetve azok eltéréseit vizsgáljuk. az eredmény közvetlenül értelmezhetö és értékelhetö, mivel áttételek nélkül világossá válik, mely térség lett relatíve gazdagabb vagy szegényebb az adott tényezöben.

Bonyolult a helyzet a (változó) „helyi” szintekre épülő vertikális vizsgálat esetében. Itt ugyanis eltérỏ minöségek statikus mennyiségi kapcsolatát kívánjuk feltárni és értékelni. Ez utóbbihoz azonban hiányzik az a - ,helyi" szinttől függően is változó mérce, amely az értékelés alapja lehetne. Ráadásul a keresett, tényezők közötti mennyiségi viszony önmaguk minöségétöl függöen is változik. A hiány úgy hidalható át, hogy valamely tényezöt ( $\mathrm{pl}$. a népességszámot, gazdasági fejlettséget stb.) független, mást függő változónak tekintünk, és viszont, illetve mérjük a közöttiik levő kapcsolat szorosságát. Viszonylag teljes áttekintést a jelzett szférában korrelációs mátrix kidolgozásával nyerhetünk, amely táblázatba foglalja a tényezök (változók) páronként számszerüsített kapcsolatait, Hipotézisünk szerint a tényezők közötti kapcsolat szorossága kifejezi a vertikális egyensúly elemeit (pl. a népességszám és a fajlagos jövedelmek területi kapcsolata a vertikális gazdasági egyensúly egyik fö mutatója lehet). Ezt azért is tehetjük, mert a területi szerkezet - különböző aggregáltsági fokon megjelenő tényezői között logikai (és tapasztalati) egymásra hatás van, amelynek mértékét és irányait a korrelációs együttható számértéke kifejezheti. Mikroökonómiai szinten, amikor egy vállalat vagy egy ember (embercsoport) megtelepedésének ,helyi” feltételeit vizsgáljuk akkor a „vertikális” kapcsolatok naturális mutatókkal is kifejezhetök. Pl. a vállalkozó számára az üzemtelepítéshez rendelkezésre áll-e a szükséges nagyságú és minőségú terület, beszerezhetők-e racionális feltételek mellett a termelési eszközök, van-e mozgósítható, szakképzett munkaerő, az értékesítési lehetöségek (a terméket vagy szolgáltatást felvevő piac) megfelelőek-e. Mezo- és makroszinten azonban az ilyen típusú mérlegeléshez korlátozottak a lehetőségek.

Vizsgálatainkat regionális és megyei szinten végeztük. Az elsỏ - mint látni fogjuk - fokozottan kísérleti jellegü; azért végeztük el, mert a területi egységek kis száma többoldalú közelítést tesz lehetővé, és a lehetséges fenntartások ellenére bizonyos 
módszertani tanulságul szolgálhat. Számításainkban általánosságban a KSH-tól közvetlenül megszerezhetö adatokra támaszkodtunk (Területi Statisztikai Évkönyv 1997. és 2003. évi köteteiben foglalt adatok). Egy esetben tértünk el: a jövedelemtermelés és -felhasználás regionális szintủ számításakor. A felhasználás becsléséhez a KSH különkiadványából („Bruttó hazai termék 2002”) indultunk ki, amely országos összesítésben, de tételek szerint részletezve közli a GDP felhasználásának adatait. Ezt kombináltuk a 2003. évi évkönyvben megyékre, illetve régiókra bontott beruházási és háztartási jövedelmekkel, valamint kiegészítettük a becsült kormányzati és önkormányzati kiadásokkal, illetve társadalmi juttatásokkal.

\section{A vizsgálatok szintjei}

A mikro-szintủ vertikális vizsgálat, amelyre tulajdonképpen a telephelyválasztás módszere is épül - a megközelítés logikáját tekintve - kiterjeszthetö mezoszintre is. Ez esetben viszont sérül a pontosság. Ha pl. egy települést vizsgálunk, akkor aggregált elemzés tárgya lehet - a népesség számából, kormegoszlásából és egyéb ismérvekból kiindulva - a szükséges szolgáltatási kapacitások nagysága, mint a lakások, osztálytermek, háziorvosi rendelök stb. száma. Ilyen vizsgálathoz általában népességszámra vagy népességcsoportra ( $/$ före, 1000 före stb.) jutó normákat szoktak alkalmazni. Kis vagy közepes nagyságú településben az így kapott szükségleti számok - feltételezve a módszer korrekt használatát - jól tükrözik a valóságot, elsősorban akkor, ha az intézmények megközelíthetősége nem kíván túlzott időráfordítást az igénybe vevőktöl. Nagylétszámú és nagy térbeni kiterjedésủ település esetén a település egészére számított szolgáltatási (kapacitás-)igény kielégítése torzulhat, pl. azért, mert több, azonos rendeltetésủ intézményt eltérö megközelítési feltételek mellett lehet igénybe venni, így egyesek kapacitása kihasználatlan marad, mások túlzsúfolttá válnak. A vizsgálati térség növekedésével a torzulás fokozódik. Vegyünk pl. egy kistérséget, amely 20 közigazgatási településböl áll. A kistérségre számított átlagos lakásellátottsági mutató például szakmai célra használhatatlan, mivel a települések egy részében lakáshiány, másutt pedig felesleg lehet; a különbözö előjelủ adatok az átlagban egymást kiolthatják. A sort folytatva, az egyre nagyobb térségekre kiszámított átlagok egyre megbízhatatlanabbá válnak a tervezés számára.

A naturális, vagy normatív ellátottsági mutatók alkalmazásából adódó másik hibaforrás a lehetséges horizontális összehasonlításból adódik. Ha pl. megyei szinten egybevetjük a fajlagos kiskereskedelmi kapacitásokat, illetve forgalmat és viszonyítjuk azokat a normatív értékekhez, majd közvetlenül következtetünk a fejlesztési támogatások területi megosztására, figyelmen kívül marad, vagy a szóban forgó gazdasági jelenség megyei értékei semmilyen logikai vagy gyakorlati kapcsolatban sincsenek egymással; azok alakulása sokkal inkább térségen belüli tényezóktöl, mint a népesség jövedelem termelése, szerkezete stb. függ. Mindez természetesen nem jelenti azt, hogy a kifogásolt módszereket haszontalanoknak tekinthetjük, vi- 
szont felhívja a figyelmet azok körültekintő használatára. Azt is jelzi továbbá, hogy különbözö területi szinteken álló egységek vertikális elemzése változó módszereket kíván; a területi skálán felfelé haladva csökken a naturális mutatók alkalmazásának hatásfoka, és magasabb szinteken minöségileg más típusú, összevont módszerek alkalmazása célszerủ, olyanoké amelyek összhangban vannak a döntési kompetenciákkal is. A nagyobb térségek (országok) középszintü elemekre (megyékre, régiókra) osztott vertikális vizsgálatának hagyományos módszerei helyett, vagy mellett is újabb eljárások alkalmazása célszerü, amelyek közül egyet e tanulmány mutat be.

\section{Regionális szint}

Ha elemzésünket a területi szerkezet tényezőinek kapcsolatára, a kapcsolatok szorosságára helyezzuik, akkor egy-egy jellemző számot kapunk (korrelációs együttható), amelyek a vizsgálatba vont nagyobb térség (jelen esetben az ország) strukturális viszonyait jellemzik, és nem adnak közvetlen választ a vizsgálati elemek (a régiók és a megyék) belső összefüggésére. Az így ,eltünt” információ később magasabb szinten pótolható, söt a hiảnyért a nagyobb térség területi szerkezetének a korábbiaknál mélyebb feltárása ad kárpótlást. Az ország területi szerkezetének regionális szintü vizsgálatát hét tényezőre alapoztuk, amelyek megfelelnek a vertikális egyensúlyi modell (Bartke 2001) fố tényezöinek; igaz ugyan. hogy az értékrend és az ideológia tartalmi azonosítására nem találtunk statisztikai mutatót. (Ezek számszerüsítéséhez mélyebb vizsgálatok. szociológiai felvételek szükségesek.) Az alkalmazott változók a területi szerke»eti tényezöknek csak tört részét és egysíkủan ragadják meg. A tanulmány módszertani jellege azonban ilyen korlátok mellett is lehetővé teszi az . alkalmazás lehetséges eredményeinek érzékeltetését. Figyelembe kell venni, hogy a szerkezeti tényezök száma tetszölegesen szaporítható (itt a statisztikai felmérés korlátai szabnak határt), és a mélyebb információt nyújtó szerkezeti résztényezök egy-egy fötényezö köré csoportosíthatók, gazdagítva annak tartalmát. (Így pl. a gazdasági tényezőhöz sorolható a GDP, mint fö mutató, továbbá az alkalmazásban állók száma, az egy alkal mazottra jutó GDP, a múködỏ vállalkozások száma stb.).

Tanulmányunkban a terület nagyságával reprezentáljuk a természeti tényezőt, a lakásállománnyal a mủvi környezetet, a népességszámmal a társadalmat, az alkalmazásban állókkal és a GDP-vel a gazdaságot, a mezőgazdasági alkalmazottak, illetve a fizikai foglalkozásúak számával az életmódot. Ez utóbbi elsősorban a mezögazdasági alkalmazottak számával, mint közvetett mutatóval jellemezhetö, tekintettel a mezőgazdasági termelés területhez, éghajlathoz, biológiai ciklusokhoz való kötöttségére és más feltételekre, amelyek sajátos arculatot adnak a munkának, az időfelhasználásnak, a fogyasztásnak, a szokásoknak stb. (1. táblázat). A jelzett szerkezeti változók alapján korrelációs mátrixot állítottunk össze, amely számszerüsíti a tényezök páronkénti szorosságát (2. táblázat). 
Bartke István : A területi egyensúlyok változása 1997 és 2002 között.

Tér és Társadalom 20. évf. 2006/2. 23-45. p.

\section{TÁBLÁZAT}

A területi szerkezet néhány tényezöje 2003

(Some Factors of Spatial Structure 2003)

\begin{tabular}{|c|c|c|c|c|c|c|c|}
\hline Régió & $\begin{array}{c}\text { Terïlet } \\
(\text { ezer } \\
\left.\mathrm{km}^{2}\right)\end{array}$ & $\begin{array}{l}\text { Lakásáll. } \\
\text { (ezer db) }\end{array}$ & $\begin{array}{l}\text { Népesség } \\
\text { (ezer fö) }\end{array}$ & $\begin{array}{l}\text { Alk.- } \\
\text { ban } \\
\text { állók } \\
\text { (ezer } \\
\text { fó) }\end{array}$ & $\begin{array}{c}G D P \\
(2002) \\
(M r d F t)\end{array}$ & $\begin{array}{c}\text { Mezög. }-i \\
\text { alk. } \\
\text { (ezerfö) }\end{array}$ & $\begin{array}{c}\text { Fizikai } \\
\text { fogl. } \\
\text { (ezer } \\
\text { fö) }\end{array}$ \\
\hline K.Magy.-o & 6.92 & 1244 & 2825 & 947 & 7636 & 10 & 388 \\
\hline K.Dun.túl & 11,12 & 427 & 1114 & 292 & 1631 & 14,4 & 171 \\
\hline Ny.Dun.túl & 11,33 & 396 & 1004 & 301 & 1713 & 13.5 & 178 \\
\hline D.Dun.túl & 14,17 & 389 & 989 & 229 & 1194 & 17,3 & 120 \\
\hline É.Magy.-o & 13,43 & 501 & 1289 & 274 & 1357 & 9,3 & 146 \\
\hline É.-Alföld & 17,73 & 595 & 1554 & 341 & 1653 & 20,2 & 182 \\
\hline D.-Alföld & 18,33 & 582 & 1367 & 313 & 1556 & 21,9 & 169 \\
\hline Orszö̈ssz. & 93,03 & 4134 & 10142 & 2697 & 16740 & 106,6 & 1354 \\
\hline
\end{tabular}

Forrás: Saját számítás.

2. TÁBLÁZAT

Korrelációs mátrix

(Correlation Matrix)

\begin{tabular}{lcccccc}
\hline & Terilet Lakásáll. & Népesséǵg & $\begin{array}{c}\text { Alk.- } \\
\text { ban }\end{array}$ & GDP & Mezóg.alk. & $\begin{array}{c}\text { Fizikai } \\
\text { fogl. }\end{array}$ \\
\hline Terület & $-0,50789$ & $-0,493290$ & $-0,65711$ & $-0,70610$ & 0,826135 & $-0,66531277$ \\
Lakásáll. & & 0,996651 & 0,978372 & 0,962699 & $-0,32994$ & 0,960530933 \\
Népesség & & & 0,970898 & 0,951780 & $-0,33334$ & 0,954281774 \\
Alk.-ban & & & & 0,996577 & $-0,42544$ & 0,992023838 \\
$\quad$ GDP & & & & & $-0,46474$ & 0,985611985 \\
Mezög.alk. & & & & & & $-0,414942353$ \\
Fizikai fogl. & & & & & & \\
\hline
\end{tabular}

Forrás: Saját számítás.

Első rátekintésre szembetünő a területi szerkezet egyik alapsajátossága, nevezetesen, hogy a terület nagysága és a többi mutató között, a mezỏgazdasági alkalmazottak számát kivéve negatív a kapcsolat, erőssége pedig általában közepesnél nagyobb. Ez elsősorban a nem mezögazdasági tevékenységek térbenileg koncentrált megjelenésére utal, másodsorban arra, hogy a területnek, mint gazdasági erőforrásnak a kihasználása alacsony fokú. A mezögazdasági alkalmazottakkal jelzett, közepesnél szorosabb pozitiv kapcsolat $(0,8$ felett) is további tartalékokat jelez. A mezögazdasági termelés viszonylag alacsony jövedelemtermelö képessége is ludas abban, hogy a GDP és a terület nagysága között közepesnél erösebb a negatív kapcsolat, jóllehet ebben más tényezők is szerepet játszanak (az egyes területek relatív alkalmassága a mezőgazdasági termelésre). A korrelációs mátrix - a területtel és a mezőgazdasági alkalmazottakkal összefüggő negatív kapcsolatokon túl - pozitív és szoros értékeket mutat. Bizonyos fokig eltér a többitől a népességszám és a GDP közötti 0,95 -ös szorosság, amely a területi szerkezet egyik fỏ egyensúlyi mutatója. Ezért ezzel a 3. táblázatban részletesebben foglalkozunk. 
Bartke István : A területi egyensúlyok változása 1997 és 2002 között.

Tér és Társadalom 20. évf. 2006/2. 23-45. p.

TÉT XX. évf. 2006 - 2

A reriileti egyensúlyok változása...

\section{TÁBLÁZAT}

A népesség és a jövedelem változása

(Change in Population and Income)

\begin{tabular}{|c|c|c|c|c|c|c|}
\hline \multirow{2}{*}{ Régió } & \multicolumn{2}{|c|}{ Népesség 1000 fö } & \multirow{2}{*}{$\begin{array}{l}\text { Dinamika } \\
2003 / 1997\end{array}$} & \multicolumn{2}{|c|}{$G D P$ milliárd $F t$} & \multirow{2}{*}{$\begin{array}{l}\text { Dinamika } \\
2002 / 1997 \\
\end{array}$} \\
\hline & 1997 & 2003 & & 1997 & 2002 & \\
\hline K.Magy.-o & 2867 & 2825 & 98,0 & 3603 & 7636 & 211,9 \\
\hline K.Dun.túl & 1113 & 1114 & 100,1 & 899 & 1631 & 181,4 \\
\hline Ny.Dun.túl & 992 & 1004 & 101,2 & 879 & 1713 & 194,9 \\
\hline D.Dun.túl & 986 & 989 & 100,3 & 646 & 1194 & 184,8 \\
\hline É.Magy.-o & 1284 & 1289 & 100,4 & 729 & 1357 & 186,1 \\
\hline É.-Alföld & 1535 & 1554 & 101,2 & 894 & 1653 & 184,9 \\
\hline D.-Alföld & 1358 & 1367 & 100,7 & 892 & 1556 & 174,4 \\
\hline Orsz.össz. & 10135 & 10142 & 100,1 & 8542 & 16740 & 195,9 \\
\hline \multicolumn{3}{|c|}{ Korreláció-szorosság:népesség/GDP 1997} & \multicolumn{3}{|c|}{0,9595} & \\
\hline \multicolumn{3}{|c|}{ Korreláció-szorosság:népesség/GDP 2003} & \multicolumn{2}{|c|}{0.9518} & & \\
\hline \multicolumn{3}{|c|}{$\begin{array}{l}\text { A dinamikák korreláció-szorossága } \\
\text { Korreláció-szorosság: Term./Felh. }\end{array}$} & \multicolumn{2}{|c|}{$\begin{array}{l}-0,7092 \\
0,9933\end{array}$} & & \\
\hline
\end{tabular}

Forrás: Saját számítás.

A gazdaság térbeni elhelyezkedésének, a megoszlás viszonylag koncentrált vagy decentralizált jellegének egyik fő mutatója, vertikális egyensúlyi komponense lehet a jövedelemtermelés (GDP) népességhez viszonyított területi elhelyezkedése és annak változása. A két szerkezeti tényezỏ térbenileg döntöen párhuzamos alaḳulását mutatja a szoros korrelációs kapcsolat, 1997-ben és 2002-2003-ban egyaránt, miközben a népesség térbeni megoszlását bizonyos stabilitás, a jövedelem termelését pedig erőteljes dinamika jellemezte. Itt meg kell jegyeznünk, mint olyan körülményt, amely hozzájárult ez utóbbi dinamikához, hogy a GDP értéktípusú mutató, amelyben az árváltozások hatása is megjelenik, továbbá kézenfekvöbb volna volumenindex alkalmazása; e keretekben azonban nem volt mód az árváltozások hatásainak kiszürésére. Továbbá a mennyiségi teljesítményeket a (tisztajövedelem) elvonási technikák változásai is torzíthatják. A számítások ilyen típusú korrigálása pontosíthatja az eredményeket.

Mindezekkel együtt értelmezhetö a két szerkezeti tényezỏ (a népesség és a GDP) kapcsolatának változása; 2003-ra 1997-hez képest a korreláció szorosság - bár alig érzékelhetően - csökkent, amely itt a gazdaság viszonylag koncentrált fejlödésére utal. Ezt a következtetést erösíti meg a népességi és GDP dinamikák közötti negatív előjelủ és közepesnél erösebb korreláció-szorosság. A népesség alig változott arányai mellett a GDP a vizsgált időszak alatt 196\%-ra nőtt országosan. Régiók szerint viszont úgy differenciálódott a kép, hogy a gazdaságilag legfejlettebb régiók az országos átlagnak megfelelő vagy annál magasabb ütemben fejlödtek (NyugatDunåntúl, Közép-Magyarország), ugyanakkor a kevésbé fejlettek országos átlag alatti dinamikát mutattak. A jelzett ütemkülönbségek egyértelmüen a jövedelemtermelésnek a népesség elhelyezkedéséhez viszonyított koncentrálódásához vezettek.

Kísérletet tettünk - és erre csak regionális szinten volt mód a publikus statisztikai adatok alapján - a jövedelemtermelés és -felhasználás becslésére, illetve össze- 
hasonlítására (itt ismét fel kell hívni a figyelmet az elöző bekezdésben jelzett hibaforrások esetleges torzító hatására). A felhasznált adatokat tekintve a GDP megyei és régiószintủ bontásban rendelkezésre állt, a régió-szintủ felhasználási adatokat pedig a már jelzett forrásmunkák adatainak kombinálásával becsültük. Ami az eredményeket illeti: Közép-Magyarország tetemes jövedelemtermelési többletet realizált; Nyugat-Dunántúlon a jövedelemtermelés és -felhasználás kiegyenlített volt (némi termelési többlettel), a többi régióban azonban a felhasználás - esetenként igen nagy mértékben - meghaladta a termelést. Ilyen szempontból különösen kedvezötlen Észak-Alföld helyzete (4. táblázat).

\section{TÁBLÁZAT}

Jövedelemtermelés és felhasználás (2002, Mrd Ft) (Production and Usage of Income 2002, Mrd HUF)

\begin{tabular}{lrrrrrrr}
\hline \multicolumn{1}{c}{ Régió } & $\begin{array}{r}\text { GDP } \\
\text { term. }\end{array}$ & $\begin{array}{c}\text { Beruhá- } \\
\text { zás }\end{array}$ & $\begin{array}{c}\text { Házt. } \\
\text { jöved. }\end{array}$ & $\begin{array}{c}\text { Korm. } \\
\text { felh. }\end{array}$ & $\begin{array}{r}\text { Társ. } \\
\text { juttat. }\end{array}$ & $\begin{array}{r}\text { Felh. } \\
\text { össz. }\end{array}$ & $\begin{array}{r}\text { Term. } \\
\text { felh. }\end{array}$ \\
\hline K.Magy.-o & 7636 & 1473 & 2928 & 950 & 671 & 6022 & 1614 \\
K.Dun.túl & 1631 & 516 & 958 & 125 & 265 & 1864 & -233 \\
Ny.Dun.túl & 1713 & 487 & 846 & 122 & 241 & 1696 & 17 \\
D.Dun.túl & 1194 & 359 & 800 & 121 & 233 & 1513 & -319 \\
É.Magy.-o & 1357 & 441 & 914 & 159 & 305 & 1819 & -462 \\
É.Alföld & 1653 & 472 & 1218 & 183 & 368 & 2241 & -588 \\
D.Alföld & 1556 & 395 & 1102 & 153 & 322 & 1972 & -416 \\
\hline Orsz.össz. & 16740 & 4143 & 8766 & 1813 & 2405 & 17127 & -387 \\
\hline
\end{tabular}

Forrás: Saját számítás.

\section{Megyei szint}

E vizsgálatokba bevontuk a régiószintünél szerepeltett vertikális szerkezeti tényezőket, részben azért, hogy összehasonlíthassuk a kétféle eredményeket, ezen túl azonban szaporítottuk is a tényezők számát a kapcsolatok mélyebb elemzése végett. Ezt a célt szolgálja az is, hogy a vizsgált időszak kezdő és befejező évére is számítottunk korreláció-szorosságot; ez a periódus alatti folyamatokba is ad bizonyos betekintést.

Elemzésünkben a társadalmat, illetve a gazdaságot helyezve a központba, e két fó tényező kapcsolatának vizsgálata mellett további kiegészítö változókat és fajlagos mutatókat vonunk be abba (az alkalmazásban állók, a regisztrált munkanélküliek mellett a gazdasági fejlettség, valamint az élömunka-termelékenység mutatóját). Ezt követően elemezzük a lakásállomány, a közmủvi felszereltség, a közmủolló kapcsolatának alakulását, amelyek munkánkban a müvi környezetet (infrastruktúra) jelenítik meg (illetve következtetést engednek meg bizonyos értékrendi kérdéseket illetően). Ugyancsak az infrastruktúra körébe tartozónak tekintjük a múködö kórházi, egyetemi-föiskolai, kutató-fejlesztő kapacitásokat, részben az azokat kitöltő létszámok alapján. Az életmódot, mint szerkezeti tényezöt részben a fizikai foglalkozásúak, föként azonban a mezőgazdasági alkalmazottak képviselik. Végül a természeti környezet egy oldalát a terület nagysága jclöli. 
A társadalom és a gazdaság területi kapcsolatai

A népességgel leegyszerüsítve reprezentált társadalom és a gazdaság a területi szerkezet központi tényezői, kapcsolatukat ezért is fokozott figyelem kíséri. Ha minősíteni kívánjuk a gazdaság területi elhelyezkedését, pl. hogy az viszonylag koncentráltnak vagy decentralizáltnak stb. tekinthetö e, akkor egyik, ha nem a legjobb viszonyítási alap a társadalom területi megoszlása. Lehet természetesen más elveket is alkalmazni, pl. a fizikai térhez viszonyítani a gazdaság területi elhelyezkedését; az ilyen vizsgálatból adódó következtetési lehetőségek azonban meglehetősen szükkörủek vagy áttételeken keresztül hasznosíthatók. A társadalom és a gazdaság viszonya sokoldalú és gazdag tartalmú azért is, mert a társadalmi lét anyagi feltételeinek döntö többségét a gazdaság hozza létre, de az az anyagin túl kisugárzik a társadalom szellemi szféráira is. A mindennapi kapcsolat - bizonyos határok között - az együttes települést is kikényszeríti, jóllehet az említett korlátok bizonyos szempontokból tágulóban vannak.

\section{TÁBLÁZAT}

Megyei egyensúlyi mutatók

(Indexes of County Balance)

\begin{tabular}{|c|c|c|c|c|c|c|}
\hline \multirow[t]{2}{*}{ Megye } & \multicolumn{2}{|c|}{$\begin{array}{c}\text { Népességszám } \\
\text { (ezer fö) }\end{array}$} & \multirow{2}{*}{$\begin{array}{c}\text { Dinam. } \\
(\%)\end{array}$} & \multicolumn{2}{|c|}{$G D P M r d F t$} & \multirow{2}{*}{$\begin{array}{c}\text { Dinam. } \\
(\%)\end{array}$} \\
\hline & 1997 & 2002 & & 1997 & 2002 & \\
\hline Budapest & 1861 & 1740 & 93,5 & 2950 & 6043 & 204,8 \\
\hline Győr-M.-S. & 425 & 435 & 102,6 & 391 & 851 & 217,6 \\
\hline Vas & 269 & 269 & 100,0 & 259 & 436 & 168,3 \\
\hline Fejér & 427 & 429 & 100,5 & 420 & 665 & 158,3 \\
\hline Kom.-E. & 310 & 317 & 102,3 & 225 & 482 & 214,2 \\
\hline Pest & 1006 & 1089 & 108,3 & 653 & 1593 & 244,0 \\
\hline Zala & 298 & 299 & 100,3 & 229 & 426 & 186,0 \\
\hline Veszprém & 376 & 375 & 99,7 & 254 & 484 & 190,6 \\
\hline Tolna & 247 & 250 & 101,2 & 175 & 322 & 184,0 \\
\hline Csongrád & 422 & 428 & 101,4 & 320 & 542 & 169,4 \\
\hline Baranya & 405 & 406 & 100,2 & 273 & 497 & 182,1 \\
\hline Heves & 326 & 327 & 100,3 & 198 & 394 & 199,0 \\
\hline Hajdú-B. & 546 & 552 & 101,1 & 351 & 666 & 189,7 \\
\hline Bács-K. & 537 & 546 & 101,7 & 331 & 608 & 183,7 \\
\hline Somogy & 334 & 337 & 100,9 & 198 & 375 & 189,4 \\
\hline Jász-N.-Sz. & 417 & 419 & 100,5 & 264 & 464 & 175,8 \\
\hline BAZ. & 739 & 749 & 101,4 & 433 & 766 & 176,9 \\
\hline Békés & 399 & 399 & 100,0 & 241 & 406 & 168,5 \\
\hline Nógrád & 219 & 221 & 100,9 & 98 & 197 & 201,0 \\
\hline Szabolcs-Sz. & 572 & 588 & 102,8 & 279 & 523 & 187,5 \\
\hline Összesen & 10135 & 10175 & 100,4 & 8541 & 16740 & 196,0 \\
\hline
\end{tabular}

Forrás: Saját számítás. 
A társadalom (népesség) és a gazdaság elsődleges viszonyát számszerủsítỏ korrelációs együttható (a népesség és a GDP között) szoros kapcsolatot mutat (5. és 10. táblázat). Az együttható értéke 1997 és 2002 között csökkent (0,937-röl 0,920-ra). Ez országos viszonylatban, egyebek mellett a gazdaságnak a népesség területi elhelyezkedésétől, kis mértékben bár, de kimutatható függetlenedését, itt koncentrálódását jelzi. Ha megvizsgáljuk a horizontális egyensúly alakulását is (5. táblázat), akkor ez a következtetés, a régiószintủ vizsgálat eredményeihez hasonlóan megerösíthetö. A népesség száma 1997 és 2002 között országosan szinten maradt, ez alatt a GDP nagysága közel megduplázódott. A területi arányok a népesség esetén alig változtak, ugyanakkor a gazdaság az országos átlagnál gyorsabban fejlődött a gazdaságilag fejlettebb megyékben, illetve Budapesten (elsősorban Pest, Györ-MosonSopron, Komárom-Esztergom megyék és a főváros fejlődési üteme emelkedett ki), a kevésbé fejlett területek dinamikája egy-két kivételtől eltekintve az átlagos szint alatt maradt. Mindez megerősíti azt a korábbi feltételezést, hogy a gazdaság a vizsgált időszak alatt területileg tovább koncentrálódott. A számítások egyértelmüen mutatják az ilyen szempontból „,nyertes”, illetve ,vesztes” területi egységeket. Ha Budapest nélkül vizsgáljuk a társadalom és a gazdaság területi kapcsolatának szorosságát (10. táblázat, 11-12. sorszám), a korrelációs együttható lazább viszony mellett kis mértékü növekedést mutat, ami annak a jele, hogy a főváros nélküli térben a két tényező közötti vertikális egyensúly javult. Más oldalról viszont a Budapesttel együtt számított szorosabb kapcsolat arra utal, hogy a föváros és vidék gazdasága kölcsönhatásban van, a két tér külön-külön kezelése hibaforrásokat rejt magában. További gazdasági mutatókat tartalmaz a 6. táblázat.

Az előbbiektöl gyökeresen eltérỏ eredményeket kapunk, ha a társadalom és a gazdaság térbeni elhelyezkedését nem egymáshoz, hanem külön-külön a területhez (,fizikai térhez”) viszonyítjuk. A területnagyság és a népességszám között csökkenő intenzitású, negatív elöjelü gyenge kapcsolat mutatkozott a vizsgált időszakban, ugyanakkor sajátos, hogy a Budapest nélküli országterületen ez a viszony közepesnél erősebb, és pozitív előjelủ volt, és ugyancsak érzékelhetô csökkenést jelzett. (10. táblázat, 3-4. sorszám). E sajátos vonások arra utalnak, hogy Budapest elhagyásával az ország területi struktúrája, mint vizsgálati tárgy alapjaiban megváltozik. Figyelemre méltó az is, hogy a regionális szinten kimutatott korrelációs együttható értéke $(-0,49)$ sokkal alacsonyabb volt a megyei szintủ értéknél (2. táblázat). Vagyis ebben az összefüggésben kifejezésre jut, hogy a népesség a térségi szint növekedésével a rendelkezésre álló terület relatíve csökkenő részét veszi igénybe, illetve az igénybevétel csökkenése lassuló mértékü. A terület és a gazdaság kapcsolatát vizsgálva is hasonló következtetésre juthatunk. Ez esetben is sajátos, hogy a lényegileg közepes erösségü korrelációs együttható, amely az ország teljes területére számítva negatív elỏjelü, Budapest elhagyásával pozitívra vált. (10. táblázat, 5-6. sorszám). 


\begin{tabular}{|c|c|c|c|c|c|c|c|}
\hline \multicolumn{8}{|c|}{$\begin{array}{c}\text { 6. TÁBLÁZAT } \\
\text { Gazdasági mutatók } \\
(\text { Economical Indicators })\end{array}$} \\
\hline \multirow[t]{2}{*}{ Megye } & \multicolumn{2}{|c|}{$\begin{array}{c}\text { Alkalm.-ban } \\
1000 \text { fö }\end{array}$} & \multicolumn{2}{|c|}{$\begin{array}{c}\text { GDP/alkalm. } \\
\text { millió Ft }\end{array}$} & \multicolumn{2}{|c|}{$\begin{array}{c}\text { Mük. vállalk. } \\
1000 \mathrm{db}\end{array}$} & \multirow{2}{*}{$\begin{array}{l}\text { GDP/fö } \\
\text { millió } F t \\
2002\end{array}$} \\
\hline & 1997 & 2003 & 1997 & 2002 & 1997 & 2003 & \\
\hline Budapest & 650 & 736 & 4,54 & 8,21 & 215 & 250 & 3,49 \\
\hline Györ-M-S. & 110 & 133 & 3,55 & 6,4 & 31 & 40 & 1,94 \\
\hline Vas & 76 & 85 & 3,41 & 5,13 & 16 & 20 & 1,63 \\
\hline Fejér & 103 & 117 & 4,08 & 5,68 & 27 & 34 & 1,55 \\
\hline Kom.-E. & 66 & 82 & 3,41 & 5,88 & 21 & 26 & 1,53 \\
\hline Pest & 139 & 212 & 4,69 & 7,51 & 73 & 97 & 1,45 \\
\hline Zala & 74 & 83 & 3,14 & 5,13 & 23 & 26 & 1,43 \\
\hline Veszprém & 87 & 93 & 2,92 & 5,2 & 25 & 31 & 1,31 \\
\hline Tolna & 54 & 56 & 3,24 & 5,75 & 15 & 19 & 1,29 \\
\hline Csongrád & 92 & 105 & 3,48 & 5,16 & 32 & 35 & 1,27 \\
\hline Baranya & 84 & 97 & 3,25 & 5,12 & 29 & 33 & 1,23 \\
\hline Heves & 64 & 74 & 3,09 & 5,32 & 18 & 23 & 1,21 \\
\hline Hajdú-B. & 112 & 126 & 3,13 & 5,29 & 32 & 39 & 1,21 \\
\hline Bács-K. & 103 & 121 & 3,21 & 5,02 & 35 & 40 & 1,11 \\
\hline Somogy & 68 & 76 & 2,91 & 4,93 & 23 & 25 & 1,11 \\
\hline Jász-N.-Sz. & 86 & 96 & 3,07 & 4,83 & 22 & 26 & 1,11 \\
\hline $\mathrm{BAZ}$ & 151 & 158 & 2,87 & 4,85 & 34 & 43 & 1,03 \\
\hline Békés & 79 & 88 & 3,05 & 4,61 & 22 & 25 & 1,02 \\
\hline Nógrád & 40 & 42 & 2,45 & 4,69 & 10 & 13 & 0,9 \\
\hline Szab.-Sz. & 96 & 118 & 2,88 & 4,43 & 29 & 38 & 0,9 \\
\hline Összesen & 2334 & 2698 & 3,17 & 6,2 & 734 & 883 & 1,65 \\
\hline
\end{tabular}

Foırás: Saját számítás.

A teriileti versenyképesség vizsgálata (II. táblázat)

Az utóbbi másfél évtizedben fokozott szakmai figyelem irányul az egyes területek, települések versenyképességére. A témakör korábban sem volt ismeretlen, kísérletek is történtek egyes oldalainak kifejezésére. Egyebek mellett új ösztönzést adott, a témakör müvelésére az Európai Unió ama törekvése, hogy az integráció a világ legversenyképesebb térsége legyen. Az irányítók a területi versenyképesség sajátos mutatóját dolgozták ki, amely az élömunka-termelékenység mellett magába ötvözi a foglalkoztatottság fokát is. Ezt a felfogást a kutatók számottevö csoportja osztja (Lengyel 2003; Barna-Molnár-Juhász 2005 stb.). Kétdimenziós jellege (és bizonyos elvi fenntartások) miatt e munkában nem tudjuk az egyébként tetszetös konstrukciót felhasználni. Számításunkban így csak az élőmunka-termelékenység (GDP/alkalmazásban állók) meglehetősen egysíkú mutatóját alkalmazhatjuk. Hozzá 
kell tenni ehhez, a területi versenyképesség-számítások általános hiányossága, hogy lényegileg csak egy erőforrást (a munkaerőt) számszerüsítenek, a többitöl el kell tekinteniük. A számítások föként a tökeforrások megjelenítésének hiánya miatt torzulnak; ennek közvetlen oka, hogy a vonatkozó adatok a statisztikákban nem jelennek meg. A területi versenyképesség központjában is az eröforrásokkal való gazdálkodás hatékonysága áll; az a térség, amely az elöbbiek magas szintü kihasználását teszi lehetővé és valósítja meg a vállalatok gazdálkodásán keresztül, további erőforrásokat vonz magához és fenntartja a folyamatos fejlödést. Ez pedig a térségek versenyképességének legföbb megnyilvánulása, így mércéje is lehet.

Visszatérve elemzésünkhöz a gazdasági fejlettség (GDP/fö) és az élömunkatermelékenység (GDP/alkalmazásban állók) közötti kapcsolat a vártnál gyengébb (2002-ben országosan: 0,83; Budapest nélkül 0,68). (10. táblázat 26. sorszám). Az utóbbi színvonala lényegesen kisebb mértékben differenciált, mint az elöbbié. (Az élömunka-termelékenység megyei szélső értékek közötti különbsége 2002-ben 1,8-szeres volt, a gazdasági fejlettségé pedig 3,9-szeres). A termelékenység ilyen megyeközi alakulása kétarcú jelenség; kedvezö, hogy a munkaeröforrások hasznosulása relatíve kiegyenlített, amely pozitív módon hat a jövedelmek térbeni közelítésére, ugyanakkor az alacsonyabb termelékenységü és helyi szükségletet kielégító profilok bizonyos szükösségére utal, amelyek pedig lényegesen nagyobb szerepet játszhatnának a munkanélküliség mérséklésében.

Kísérletképpen számítást végeztünk a 2002. évi adatok alapján az élömunkatermelékenység modellszerü alakulására a gazdasági fejlettség függvényében. Ez számítástechnikailag azt jelenti, hogy meghatároztuk a tényadatokhoz illeszkedö lineáris regressziófüggvényt $(\mathrm{y}=1,38 \mathrm{x}+3,54)$, amelyet a független változó (GDP/fö) 2002. évi adataira megoldva megkaptuk a függő változó (GDP/alkalmazásban állók) regresszió szerinti értékeit. (11. táblázat). Ezek, valamint az élömunkatermelékenység 2002. évi tényadatainak különbségei mutatják az ország területi egységeinek versenyképességi tartalékait (és hiányait) - a számítás adott korlátai mellett - a magyar gazdaság feltételei által generált térben. A kapott eredmények, az elözetes elképzelésekhez képest részben váratlanok. Mindenekelött a fövárost jellemzó regressziós értéknek (mint termelékenységi követelménynek) a ténylegest kis mértékben meghaladó szintje. Ez föként azzal függhet össze, hogy a számításban elszakítottuk egymástól a két, szervesen együttmüködö térséget, Budapestet és Pest megyét. Az utóbbi terület termelékenységi tényadata viszont messze meghaladja a követelményértéket (7,51 kontra 5,54). A „normatív" termelékenységi szintet föként néhány, a fejlettségi rangsor első felében található megye "teljesíti túl" (Györ-Moson-Sopron, Komárom-Esztergom, a már említett Pest és Tolna); ezeken kívül figyelemre méltó Heves és Hajdú-Bihar megyék relatíve magas termelékenységi mutatója. Nem éri el a normatív színvonalat Vas, Zala és Veszprém megye, valamint a fejlettségi rangsor második felében elhelyezkedö megyék többsége.

A bemutatott regresszió-analízisben a horizontális és a vertikális (egyensúlyi vizsgálat) összekapcsolása megvalósul, mivel a vizsgálati egységek mint két-két (területi) tényező elemei egyaránt rendelkeznek a két tényező tulajdonságaival. Ez a kettős minöség úgy jelenik meg, hogy a megyék az analizis által kcltett lineáris 
térben két-két koordinátával rendelkezỏ elemként helyezkednek el. A koordináták hossza a tulajdonságok egymáshoz való (mennyiségi) viszonyát fejezi ki az adott elemekben. Az utóbbiak csoportosithatók úgy, hogy a bennük lévő két tulajdonság mennyiségi viszonya szabályszerủ maradjon, amely normatívának tekinthető, miközben a koordináták hossza változik. E térbeli csoportosításból, amely lineáris stb. függvényként formalizálható, le lehet olvasni, hogy az egyik tulajdonságot hordozó mennyiséghez az elemek szabályszerủen mekkora másik tulajdonsága tartozik.

\section{A müvi környezet (infrastruktúra) föbb kapcsolatai}

A területi szerkezeti modellnek a természeti környezet utáni második alaptényezője a müvi környezet, amelyet többnyire az infrastruktúra fogalmával azonosítanak. Kétségtelen, hogy a két fogalom jelentősen átfedi egymást, de nem felel meg teljesen egymásnak. Az eltérés mértéke attól is függ, hogyan definiáljuk magát az infrastruktúrát. A terminológiai vitának itt azért sincs helye, mert a továbbiakban a mủvi környezet néhány olyan altényezőjének kapcsolatait vizsgáljuk, amelyeknek az infrastruktúrához tartozását kevéssé vitatják.

A lakásállomány területi elhelyezkedése logikailag meghatározó kapcsolatban van a népesség és a gazdaság térbeni megjelenésével. Így a várakozásnak megfelelően a terület nagyságával gyengén negatív kapcsolatot mutat, Budapesttel együtt számítva, a népességszámhoz és a GDP-hez hasonlóan. Budapest nélkül viszont a közepesnél erỏsebb és pozitív a kapcsolat; ebben, még ha az kismértékben gyengült is, a két altényező közötti egyensúlyhoz lényegesen közelebb álló állapot tükröződik. (10. táblázat, 1-2. sorszám). A lakásállomány müszaki felszereltségének és minöségi színvonalának rendkívül fontos mutatója a közüzemi víz- és csatornahálózatba való bekapcsoltság, amely az elöbbieken túl környezetvédelmi tartalommal is rendelkezik. Az utóbbi évtizedekben a vízellátás, illetve -hálózat fejlesztése gyorsabb volt a csatornázásénál, illetve a szennyvíztisztításénál; a vízhálózatba, másrészt a csatornahálózatba bekapcsolt lakások aránya között korábban erőteljesen nőtt, a vizsgált idöszakban pedig csökkent a különbség, de jelenleg is tetemes (7. táblázat). A kettỏ közötti differenciát nevezzük közmủollónak (8. táblázat). Ez a GDP-vel, 1997-ben szoros, 2002-ben pedig közepes erösségủ negatív kapcsolatot jelzett az ország egész területére számítva, ugyanakkor a Budapest nélküli térségre nem mutatott kapcsolatot egyik idópontban sem. (10. táblázat, 9-10. sorszám).

Az összefüggések meglehetös bonyolultsága miatt célszerū e kérdést jobban körüljárni. A közmủolló társadalmi értékelés szempontjából negatív fogalom, mivel azt jelzi, hogy a szennyvizet a lakásingatlanok milyen hányadáról nem vezetik el és tisztítják meg, tehát milyen mértékủ a potenciális helyi talajszennyezés. Természetes, hogy a szennyvíz elszállítása csak annak megtisztításával együtt oldja meg a problémát. Köztudott azonban, hogy a tisztító kapacitások a csatornával összegyüjtött szennyvizek mennyiségéhez képest is szúkösek. Ilyen konkrét vizsgálathoz az adatok hiányában nem volt mód. Visszatérve a közmủollóhoz, a GDP-vel mutatott (szoros vagy közepes) negatív kapcsolat pozitív értékelést kap, ugyanis azt jelenti, hogy minél magasabb az adott terület realizált jövedelme, annál kisebb a közmủolló. Figyelemre 
Bartke István : A területi egyensúlyok változása 1997 és 2002 között.

Tér és Társadalom 20. évf. 2006/2. 23-45. p.

méltó azonban, hogy a közmủolló és a GDP (egyébként negatív irányú kapcsolata) 1997 és 2002 között gyengült. Ez azt jelenti, hogy a csatornázás valamelyest függetlenebbé vált a jövedelemszinttöl, tehát más értékrendi motívumok is hatni kezdtek. A folyamat gazdasági tartalma ugyanis az, hogy a jövedelem nagyságától függően törekszenek a helyi talajszennyezés mérséklésére. Értékrendi tartalom pedig, hogy a helyi társadalmak fontosnak tartják a környezet védelmét, anyagi eszközöket fordítva arra, föként azért, mert a szennyvizek elvezetése, illetve tisztítása mindenekelőtt a helyi lakosság érdekében áll.

\section{TÁBLÁZAT}

(Társadalmi és infrastrukturális mutatók 1. )

(Social and Infrastructural Indicators 1. )

\begin{tabular}{|c|c|c|c|c|c|c|c|c|}
\hline \multirow[t]{2}{*}{ Megye } & \multicolumn{2}{|c|}{$\begin{array}{c}\text { Reg. } \\
\text { munkanélk. } \\
1000 \text { fö }\end{array}$} & \multicolumn{2}{|c|}{$\begin{array}{l}\text { Lakásállo- } \\
\text { mány } 1000 \mathrm{db}\end{array}$} & \multicolumn{2}{|c|}{$\begin{array}{c}\text { Vízhál. } \\
\text { bekapcs. \% }\end{array}$} & \multicolumn{2}{|c|}{$\begin{array}{l}\text { Csatorna } \\
\text { hálózatba } \\
\text { bekapcs. \% }\end{array}$} \\
\hline & 1997 & 2003 & 1997 & 2003 & 1997 & 2003 & 1997 & 2003 \\
\hline Budapest & 40,6 & 19 & 819 & 835 & 98,5 & 98.3 & 90,5 & 94,1 \\
\hline Győr-M.-S. & 11,5 & 8,1 & 159 & 171 & 96,7 & 94,7 & 46,9 & 69,0 \\
\hline Vas & 8,4 & 6,7 & 102 & 105 & 95,2 & 96,2 & 47,3 & 58,0 \\
\hline Fejér & 18,0 & 13,2 & 158 & 163 & 92.6 & 95,7 & 42,8 & 64,0 \\
\hline Komárom-E. & 14,8 & 7,6 & 119 & 121 & 94,1 & 95,5 & 54,5 & 71,9 \\
\hline Pest & 29,8 & 16,8 & 369 & 409 & 82,1 & 91,0 & 22,7 & 47,4 \\
\hline Zala & 12,2 & 9,8 & 116 & 120 & 94,1 & 95,8 & 46,2 & 59,2 \\
\hline Veszprém & 15,8 & 12,4 & 143 & 143 & 96,5 & 99,3 & 45,8 & 67,1 \\
\hline Tolna & 14,7 & 11,4 & 97 & 97 & 90,9 & 93,8 & 31,1 & 43,3 \\
\hline Csongrád & 18,1 & 15,7 & 182 & 184 & 88,8 & 89,1 & 35,7 & 46,7 \\
\hline Baranya & 22.5 & 19,7 & 156 & 159 & 94,5 & 95,0 & 53,8 & 64,8 \\
\hline Heves & 16,2 & 13,1 & 132 & 131 & 89,8 & 93,1 & 31,5 & 45,0 \\
\hline Hajdú-B. & 34,7 & 27,9 & 210 & 215 & 91.4 & 94,0 & 34,0 & 42,8 \\
\hline Bács-K. & 24,7 & 22,1 & 227 & 233 & 82.7 & 85.4 & 21,8 & 33,5 \\
\hline Somogy & 17,5 & 17,6 & 132 & 133 & 90,6 & 94,7 & 35,8 & 49,6 \\
\hline Jász-N.-Sz. & 25,0 & 17,9 & 168 & 169 & 90,0 & 94,1 & 27,2 & 42,0 \\
\hline BAZ & 58,2 & 53,6 & 281 & 281 & 80,8 & 85,8 & 38,8 & 53,4 \\
\hline Békés & 23,9 & 17,2 & 167 & 166 & 86,8 & 90,4 & 22,6 & 36,1 \\
\hline Nógrád & 14,2 & 13,3 & 88 & 89 & 87,1 & 86,5 & 28,7 & 44,9 \\
\hline Szab.-Sz. & 43 & 36,9 & 207 & 211 & 83,5 & 90,0 & 23.9 & 41,2 \\
\hline Össz. & 464 & 359,9 & 4032 & 4134 & 90,6 & 93,3 & 46,0 & 59,1 \\
\hline
\end{tabular}

Forrás: Saját számítás.

A 8. táblázat adataiból kitetszik, hogy a közmủolló minden megyében számottevően záródott 1997 és 2003 között, söt a gazdaságilag hátrányos helyzetü területeken gyakran nagyobb arányban (pl. Nógrád megye), mint a gazdasági fejlettség skáláján elökelöbb helyet elfoglalók esetében. Ezt is tükrözi, hogy a Budapest nélküli országterületre számítva a GDP és a közmüolló között korrelációs kapcsolat lényegileg nincs. Meg kell jegyezni, amely a folyamat pozitív voltát nem befolyásolja, hogy 
a csatornahálózat fejlesztéséhez - természetesen pályázati alapon - jelentős arányú állami támogatást lehetett igénybe venni.

\section{TÁBLÁZAT}

(Társadalmi és infrastrukturális mutatók 11.)

(Social and Infrastructural Indicators II.)

\begin{tabular}{|c|c|c|c|c|c|c|c|c|}
\hline \multirow[t]{2}{*}{ Megye } & \multicolumn{2}{|c|}{$\begin{array}{c}\text { Közmüolló } \\
\%\end{array}$} & \multicolumn{2}{|c|}{$\begin{array}{c}\text { Egyetem, föisk. } \\
\text { h. } 1000 \text { fö }\end{array}$} & \multicolumn{2}{|c|}{$\begin{array}{c}\text { Kutató-fejlesztö } \\
1000 \text { fö }\end{array}$} & \multicolumn{2}{|c|}{$\begin{array}{c}\text { Müködö kórház } \\
\text { ágy } 1000 \mathrm{db}\end{array}$} \\
\hline & 1997 & 2003 & 1997 & 2003 & 1997 & 2003 & 1997 & 2003 \\
\hline Budapest & 8,0 & 4,2 & 61,1 & 87,3 & 7,15 & 9,40 & 24,2 & 22,5 \\
\hline Győr-M.-S. & 49,8 & 25,7 & 8,4 & 11,3 & 0,31 & 0,47 & 3,7 & 3,4 \\
\hline Vas & 47,9 & 38,2 & 3,0 & 2,9 & 0,08 & 0,10 & 2,0 & 1,9 \\
\hline Fejér & 49,8 & 31,7 & 4,4 & 5,9 & 0,14 & 0,35 & 2,9 & 2,6 \\
\hline Kom.-E. & 39,6 & 23,1 & 1,1 & 1,9 & 0,02 & 0,13 & 2,1 & 1,9 \\
\hline Pest & 59,4 & 43,6 & 5,6 & 6,6 & 0,36 & 0,66 & 3,8 & 3,6 \\
\hline Zala & 47,9 & 36,6 & 2,1 & 2,6 & 0.05 & 0,04 & 2,7 & 2,7 \\
\hline Veszprém & 50,7 & 32,2 & 4,2 & 6,1 & 0,25 & 0,29 & 3,2 & 3.1 \\
\hline Tolna & 59,8 & 40,5 & 0,8 & 0,8 & 0,05 & 0,01 & 1,7 & 1,6 \\
\hline Csongrád & 53,1 & 42,4 & 13,6 & 16,9 & 0,82 & 0,89 & 3,5 & 3,4 \\
\hline Baranya & 40,7 & 30,2 & 9,9 & 13,8 & 0,43 & 0,56 & 3,7 & 3,5 \\
\hline Heves & 58,3 & 48,1 & 3,7 & 5,1 & 0,11 & 0,16 & 2,6 & 2,6 \\
\hline Hajdú-B. & 57,4 & 51,2 & 12,2 & 15,5 & 0,62 & 0,95 & 4,2 & 4,4 \\
\hline Bács-K. & 60,9 & 51,9 & 3,6 & 4,5 & 0,1 & 0,24 & 3,8 & 3,5 \\
\hline Somogy & 54,8 & 45,1 & 2,0 & 2,5 & 0,03 & 0,13 & 2,4 & 2,4 \\
\hline Jász-N.-Sz. & 62,8 & 52,1 & 2,8 & 3,3 & 0,14 & 0,13 & 3,0 & 2,7 \\
\hline $\mathrm{BAZ}$ & 42,0 & 32,4 & 7,3 & 7,9 & 0,25 & 0,42 & 5,4 & 5,4 \\
\hline Békés & 64,2 & 54,3 & 2,0 & 2,3 & 0,06 & 0,09 & 2,9 & 2,8 \\
\hline Nógrád & 58,4 & 41,6 & 0,6 & 0,8 & 0,02 & 0,01 & 1,7 & 1,6 \\
\hline Szab.-Sz. & 59,6 & 48,8 & 4,4 & 6,2 & 0,18 & 0,16 & 4,0 & 4,1 \\
\hline Összesen & 44,6 & 34,2 & 152,8 & 204,9 & 11,15 & 15,18 & 83,5 & 79,8 \\
\hline
\end{tabular}

Forrás: Saját számítás.

A mủvi kỏrnyezet altényezői közül vizsgáltuk még a kórházi, az egyetemiföiskolai, illetve a kutató-fejlesztő kapacitások területi elhelyezkedését és azok változását (8. táblázat). A múködó kórházi ágyak kapcsolata a GDP-vel lényegesen szorosabb, mint a népességgel (10. táblázat, 20-21., ill. 29-30. sorszám). Ez azonban csak a teljes országterületre érvényes; a Budapest nélküli területen viszont közepes erősségú a népességgel, és közepes körüli a GDP-vel való kapcsolat. A korrelációs egyưtthatók egymáshoz viszonyított értékének ilyen változása feltételezhetően a GDP és a kórházi kapacitások nagyarányú fôvvárosi koncentrációjára vezethető vissza. Az egyetemi-föiskolai kapacitások nagyságát a hallgatók számával fejeztük ki (8. táblázai); a népességgel és a GDP-vel egyaránt szoros kapcsolatok mutatkoztak; Budapest nélkül számítva azonban értékük a közepes szintet sem érte el. Itt ismét a „Budapest szindrómával” találkozunk, akár csak a kutatói kapacitások esetében (10. táblázat, 18-19., 31-32., illetve 33-34. sorszám). 


\section{Életmód és értékrend}

Az életmód, mint igen összetett kategória és szerkezeti tényezö jellemzésére a mezögazdaságban alkalmazásban állók és a fizikai alkalmazásúak számát emeltük ki, közülük az elsőnek említett társadalmi csoport jelent - foglalkozásának sajátosságai miatt életmódban és életformában a társadalom többségétől elkülönülö részt (9. táblázat).

9. TÁBLÁZAT

(Foglalkoztatási szerkezet)

(Employement Structure)

\begin{tabular}{|c|c|c|c|c|c|c|c|}
\hline \multirow{2}{*}{ Megye } & \multicolumn{3}{|c|}{ Mezög.-i alkalm.-ban 1000} & \multicolumn{3}{|c|}{ Fizikai foglalkozásúak 1000} & \multirow{2}{*}{$\begin{array}{c}\text { Terület } \\
\mathrm{km}^{2}\end{array}$} \\
\hline & 1997 & 2003 & $2003 / 1997$ & 1997 & 2003 & $2003 / 1997$ & \\
\hline Budapest & 3,8 & 3,4 & 98 & 295 & 271 & 92 & 525 \\
\hline Györ-M.-S. & 8,1 & 5,8 & 72 & 69 & 76 & 110 & 4208 \\
\hline Vas & 6,3 & 3,5 & 56 & 51 & 52 & 102 & 3336 \\
\hline Fejér & 8,6 & 7,1 & 83 & 67 & 69 & 103 & 4359 \\
\hline Kom.-E. & 6,3 & 3,7 & 59 & 41 & 48 & 117 & 2265 \\
\hline Pest & 8,3 & 6,7 & 81 & 81 & 116 & 143 & 6393 \\
\hline Zala & 6 & 4,1 & 68 & 47 & 50 & 106 & 3784 \\
\hline Veszprém & 5,6 & 3,6 & 64 & 55 & 54 & 98 & 4493 \\
\hline Tolna & 7,7 & 4,3 & 56 & 34 & 31 & 91 & 3703 \\
\hline Csongrád & 8,7 & 5,7 & 87 & 54 & 54 & 100 & 4263 \\
\hline Baranya & 8,4 & 6,8 & 81 & 48 & 47 & 98 & 4429 \\
\hline Heves & 5 & 3,4 & 68 & 39 & 40 & 103 & 3637 \\
\hline Hajdú-B. & 11,3 & 9,2 & 81 & 67 & 67 & 100 & 6211 \\
\hline Bács-K. & 12,6 & 9 & 71 & 65 & 67 & 103 & 8445 \\
\hline Somogy & 9,2 & 6,2 & 67 & 41 & 41 & 100 & 6036 \\
\hline Jász-N.-Sz. & 10,2 & 6,4 & 63 & 54 & 53 & 98 & 5582 \\
\hline $\mathrm{BAZ}$ & 8,6 & 5 & 58 & 94 & 84 & 89 & 7247 \\
\hline Békés & 9,4 & 7,2 & 77 & 50 & 48 & 96 & 5631 \\
\hline Nógrád & 2 & 0,9 & 45 & 24 & 23 & 96 & 2546 \\
\hline Szab.-Sz. & 5,5 & 4,7 & 85 & 59 & 62 & 105 & 5936 \\
\hline Össz. & 151,6 & 106,6 & 70 & 1338 & 1355 & 101 & 93030 \\
\hline
\end{tabular}

Forrás: Saját számítás.

A gazdaság (GDP) és a mezőgazdasági alkalmazottak között negatív irányú, de gyenge a kapcsolat; ebben kifejezésre juthat a mezőgazdaság viszonylag alacsony jövedelemtermelö-képessége; más oldalról viszont a föváros nélküli országterületen a kapcsolat pozitív irányúra vált, de közepesnél gyengébb. Ebben nyilvánvalóan megmutatkozik, hogy a mezőgazdaság elsősorban a „vidéki” térségek struktúraalkotó ágazata, és ott számottevő, foglalkoztatást és jövedelmet nyújtó tén yezö. Az életmód és életforma mezögazdasági keresőket, illetve a kapcsolódó társadalmi 
Bartke István : A területi egyensúlyok változása 1997 és 2002 között.

Tér és Társadalom 20. évf. 2006/2. 23-45. p.

TÉT XX. évf. $2006=2$

A területi egyensúlyok változása ...

43

rétegeket jellemző sajátosságait föként a rurális térségek fejlesztési programjainak

készítésekor kell figyelembe venni.

10. TÁBLÁZAT

A területi szerkezet tényezöi közötti kapcsolatok

(Connections between the Factors of Spatial Structure)

\begin{tabular}{lcc}
\hline \multicolumn{1}{c}{ Szerkezeti tényezók } & \multicolumn{2}{c}{ Korrelációs együithatók } \\
\cline { 2 - 3 } & Budapesttel & Budapest nélkül \\
\hline 1. Terület / lakásállomány 1997 & $-0,2196096$ & 0,737506 \\
2. Terület / lakásállomány 2003 & $-0,2094789$ & 0,702457 \\
3. Terület / népességszám 1997 & $-0,1677690$ & 0,691092 \\
4. Terület / népességszám 2003 & $-0,1179130$ & 0,667662 \\
5. Terület / GDP 1997 & $-0,4338826$ & 0,511841 \\
6. Terület / GDP 2002 & $-0,4326139$ & 0,427964 \\
7. Lakásállomány / népesség 1997 & 0,9943566 & 0,992061 \\
8. Lakásállomány / népesség 2003 & 0,9888696 & 0,993803 \\
9. Közmüolló / GDP 1997 & $-0,8041766$ & $-0,070070$ \\
10. Közmüolló GDP 2002 & $-0,6621630$ & $-0,093800$ \\
11. Népességszám / GDP 1997 & 0,9379526 & 0,893981 \\
12. Népességszám / GDP 2002 & 0,9204206 & 0,904542 \\
13. Nép. din. / GDP din. 2002/1997 & 0,4153848 & 0,757676 \\
14. GDP / alk.-ban állók 1997 & $-0,2635962$ & 0,435396 \\
15. GDP / alk.-ban állók 2002 & $-0,1251048$ & 0,407776 \\
16. GDP / vállalk.száma 1997 & 0,9904649 & 0,914112 \\
17. GDP / vállalk.száma 2002 & 0,9920799 & 0,973012 \\
18. Népesség / egyet.hallg. 1997 & 0,8866464 & 0,384978 \\
19. Népesség / egyet.hallg. 2003 & 0,8455295 & 0,323878 \\
20. Népesség / múk.k.ágy 1997 & 0,9245550 & 0,761537 \\
21. Népesség / mük.k.ágy 2003 & 0,8924124 & 0,707052 \\
22. GDP / alk-ban állók 1997 & 0,9960087 & 0,903696 \\
23. GDP / alk-ban állók 2002 & 0,9965126 & 0,945947 \\
24. GDP alk./népesség 1997 & 0,6723948 & 0,520358 \\
25. GDP alk./népesség 2002 & 0,7606551 & 0,477556 \\
26. GDP fö/GDP alk. 2002 & 0,8360698 & 0,683130 \\
27. GDP / reg. munkanélk. 1997 & 0,4016975 & 0,440977 \\
28. GDP / reg. munkanélk. 2002 & 0,0635726 & 0,188088 \\
29. GDP / mük.k.ágy 1997 & 0,9872291 & 0,661059 \\
30. GDP / mük.k.ágy 2002 & 0,9757507 & 0,503574 \\
31. GDP / egyet.stb hallg. 1997 & 0,8508953 & 0,462522 \\
32. GDP / egyet.stb hallg. 2002 & 0,9613690 & 0,335873 \\
33. GDP / kutatók 1997 & 0,9834208 & 0,443053 \\
34. GDP / kutatók 2002 & 0,9821651 & 0,561761 \\
35. GDP fó/GDP alk. 1997 & 0,7074502 & 0,623395 \\
\hline
\end{tabular}

Forrás: Saját számítás. 
Bartke István : A területi egyensúlyok változása 1997 és 2002 között.

Tér és Társadalom 20. évf. 2006/2. 23-45. p.

\section{TÁBLÁZAT}

Az élömunka-termelékenység alakulása (2002, millió Ft/alk.) (Change of Live-work Activity 2002 (Million HUF/employee)

\begin{tabular}{lrcc}
\hline \multicolumn{1}{c}{ Megye } & Tényadat & Regr.sz.adat & Hiány/többlet \\
\hline Budapest & 8,21 & 8,36 & $-0,15$ \\
Györ-M-S. & 6,4 & 6,22 & 0,18 \\
Vas & 5,13 & 5,79 & $-0,66$ \\
Fejér & 5,68 & 5,68 & 0 \\
Komárom-E. & 5,88 & 5,65 & 0,23 \\
Pest & 7,51 & 5,54 & 1,97 \\
Zala & 5,13 & 5,51 & $-0,38$ \\
Veszprém & 5,2 & 5,35 & $-0,15$ \\
Tolna & 5,75 & 5,32 & 0,43 \\
Csongrád & 5,16 & 5,29 & $-0,13$ \\
Baranya & 5,12 & 5,24 & $-0,12$ \\
Heves & 5,32 & 5,21 & 0,11 \\
Hajdú-B. & 5,29 & 5,21 & 0,08 \\
Bács-K. & 5,02 & 5,07 & $-0,05$ \\
Somogy & 4,93 & 5,07 & $-0,14$ \\
Jász-N.-Sz. & 4,83 & 5,07 & $-0,24$ \\
BAZ & 4,85 & 4,96 & $-0,11$ \\
Békés & 4,61 & 4,95 & $-0,34$ \\
Nógrád & 4,69 & 4,78 & $-0,09$ \\
Szab.-Sz. & 4,43 & 4,78 & $-0,35$ \\
\hline
\end{tabular}

Forrás: Saját számítás.

\section{Irodalom}

Barna K.-dr. Molnár T.-Juhász Rózsa T. (2005) Megújuló teruletpolitika: előtérben a terulleti versenyképesség. - Területi Statisztika. 6. 542-555. o.

Bartke I. (2001) Területi egyensúlyok. - Tér és Társadalom. 1. 25-38. o.

Bruttó hazai termék 2002. (2004) KSH, Budapest.

Enyedi Gy. (1996) Regionális folyamatok Magyarországon az átmenet idôszakában. Budapest.

Lengyel I. (2003) Verseny és terilleti fejlödés. JATEPress, Szeged.

Lengyel I.-Rechnitzer J. (2004) Regionális gazdaságtan. Dialóg Campus Kiadó, Budapest-Pécs.

Nemes Nagy J. (1998) A tér a társadalomkutatásban. Bevezetés a regionális tudományba. Hilscher Rezső Szociálpolitikai Egyesület, Budapest.

Nemes Nagy J. (2003) A regionális tudomány dualitása és paradigmái - hazai tükörben. - Tér és Társadalom. 1. 1-17. o.

Nijkamp, P. (1990) Spatial Developments in the United States of Europe: Glorious Victories or Ignominious Defeats? - Papers of the Regional Scicnce Association. 69. 1-10. o.

Rechnitzer J. (2005) Tưkör által nem elhomályosítva. (A posztmodern, a paradigmák, a main stream és a csábítás ördöge a regionális tudományban) - Tér és Társadalont. 3-4. 1-12, o,

Teriületi Statisztikai Évkönyv (1997). KSH, Budapest.

Terïleti Statiszzikai Évkönyv (2002). KSH, Budapest. 


\section{CHANGING STATES OF THE REGIONAL EQUILIBRIA BETWEEN 1997 AND 2002}

\section{ISTVÁN BARTKE}

For the purpose of studiing regional ratios (differences) and equilibria the horizontal spatial model is emploied, by which the equivalent elements (e.g. labour force) of the regional units situated close to each other and their differences can be numerically expressed. Besides the so-called vertical model can also be given very important role. The latter is able to reveal the quantitative relations among the elements of different quality (e.g. work-places, labourforces, residences etc.) within the regional units. For calculations of the vertical model one has to make use of correlation and regression analysis. By this vertical equilibria conditions may be numerically expressed in pairs of factors. Values of the regional units belonging to the equilibria states can be determined in more variants. 